\title{
CONFLICTING LEGAL REGIMES VYING FOR APPLICATION: THE OLD ADMINISTRATIVE CONTRACTS LAW OR THE MODERN PUBLIC PROCUREMENT LAW FOR ETHIOPIA
}

\author{
Tecle Hagos Bahta
}

\section{(2017) 4 APPLJ 1}

\begin{abstract}
The Ethiopian Civil Code of 1960 contained provisions on administrative contracts. Such contracts were little known in Ethiopia during those days. However, in the absence of any legal system to govern contracts entered into by administrative authorities, the redactor of the Civil Code felt it necessary for Ethiopia to adopt the French administrative contract principles. Hence the incorporation of those principles into the Civil Code although the redactor himself admitted that it was peculiar for any Civil Code to contain administrative law principles. Since the promulgation of the Civil Code in 1960, the provisions on administrative contracts remained by and large unknown and virtually ineffective in terms of their application in governing contractual relationships between administrative authorities and private contracting parties.

In early 1990s, as part of its modernization efforts, Ethiopia enacted new laws consisting of modern public procurement law principles in order to overhaul the then existing weak and corrupt public financial management and administration, and the public procurement systems. These new laws were followed and supplanted by two successive proclamations in 2005 and 2009 both on financial administration and public procurement. However, despite what it seems to be a clear and deliberate move by the legislature, as discussed in this work, to abrogate the old administrative contracts provisions in the Civil Code, the courts in Ethiopia take cognizance thereof and apply them whenever these provisions are invoked by disputing parties.

Thus, the two conflicting legal regimes are made to co-exist in the Ethiopian legal system thereby causing confusions in the rights and obligations of contracting parties, particularly private companies and individuals entering into public procurement contracts with administrative authorities.

In this work, the nature and peculiarities of administrative contracts, how the principles enshrined in such contracts evolved in Ethiopia, and the existing problems emanating from the dilemma of trying to preserve the old administrative contracts provisions are examined and analyzed. Furthermore, the provisions of the successive proclamations by which these administrative contracts law provisions have been repealed have been critically assessed. Finally, it is shown that Ethiopia has enacted a full-fledged modern public procurement laws that are modelled on the UNCITRAL Model Law on Procurement of Goods, Construction and Services (1994) which should prevail over the old administrative contract rules in the Civil Code.
\end{abstract}




\section{CONFLICTING LEGAL REGIMES VYING FOR}

\section{APPLICATION: THE OLD ADMINISTRATIVE CONTRACTS LAW OR THE MODERN PUBLIC PROCUREMENT LAW FOR ETHIOPIA}

Tecle Hagos Bahta

LL.B, LL.M

Lecturer-at-law, Department of Law, University of Botswana; Associate Professor of Law, School of Law, Mekelle University

\section{Introduction}

The concept of "administrative contracts law" was introduced to Ethiopia in the first half of the $20^{\text {th }}$ century. In an arbitration case which was brought by a French company Societe Rialet against the then Imperial Government of Ethiopia (IGE), in re Societe Rialet $v$ Ethiopia, ${ }^{1}$ Ethiopia had to defend the case based on the French administrative contracts law rules as the rules had already matured there. The arbitral tribunal decided that "the contract to manufacture and supply alcoholic beverages granted by an Ethiopian state corporation to a French company was a public contract and, in the absence of an Ethiopian administrative law, was governed by principles of European public law". ${ }^{2}$ In the case, the arbitrators noted that the French administrative law reflected the principles of European public law. ${ }^{3}$

In 1950s, the late Professor Rene David, then one of the leading comparative lawyers, was entrusted with the mission of drafting a modern Civil Code for Ethiopia. In so doing, the French Professor felt obligated to incorporate some provisions on administrative contracts law, which essentially drew on the French administrative contracting system. This was ventured in a bid to provide for some governing rules to the hitherto arbitrary and uncharted territory within the then administrative agencies in Ethiopia. According to him, the reasons for including such rules that govern administrative contracting in the Civil Code were that it "would lead to a security in

\footnotetext{
1 Sornaraja 1986: 132, citing Sentence Arbitrate entre le Societe Rialet et le Gouvernement Ethiopien (1928-29) 8 Recueil de Decisions des Tribunales Arbit. Mixtes 742.

2132

3132.
} 
contractual relations with the government that would enhance the country's development". 4 He also particularly hoped that the clarification of the rules on administrative contracts would help attract foreign enterprises and capital to Ethiopia. ${ }^{5}$

According to Professor Rene David, the term "administrative contract" is used to "designate contracts beyond the civil code's purview, contracts that are subject to special administrative law rules". ${ }^{6} \mathrm{He}$, thus, remarks that administrative contracts cannot be dealt with in civil codes. ${ }^{7}$

However, he took the initiative to incorporate the French administrative contract rules as "the choice was open as to whether or not to use the concept of administrative contract". ${ }^{8}$ This was justified, according to him, as there was uncertainty in the area, compounded by the shortage of trained lawyers and lack of trained personnel in the government and the absence of special administrative court in Ethiopia. ${ }^{9} \mathrm{He}$ admitted that it was anomalous to incorporate rules on administrative contracts in the Civil Code. He, however, noted that the decision to do so, in the light of the then prevailing circumstances in Ethiopia, so as to set out "a clear and coherent system" 10 of administrative contracts law, was worthwhile. Hence the inclusion thereof in the Civil Code albeit in a separate or special title; i.e., Title $\mathrm{XIX}^{11}$ of the Civil Code. In so adopting the French administrative contract principles in the Ethiopian Civil Code, he further noted that, "[n]o rule of any foreign law whatsoever went into the Ethiopian Civil Code without our asking whether it was suitable for Ethiopia. We asked this question in drafting the title on administrative contracts just as we did for all the other titles of the Code". ${ }^{12}$

\footnotetext{
4 David 1967: 145.

5145.

6143.

7143.

8144.

9 144-145.

10145.

${ }^{11}$ The Civil Code contained Five Books (on Persons, Family and successions, Goods, Obligations, and Special Contracts respectively) within which are contained 22 Titles. Book V, for instance, consists of Title XV (on contracts relating to the assignment of rights), Title XVI (contracts for the performance of services), Title XVII (contracts for the custody, use or possession of chattels), Title XVIII (contracts relating to immovable property), Title XIX (administrative contracts), Title XX (Compromise and Arbitral Submission), Title XXI (Provisions dealing with law repealed by the Code) and Title XXII (Transitory provisions).

${ }_{12}$ David 1967:145-46.
} 
From this perspective, what was interesting indeed is the bold initiative by Rene David to put in place a system that would curb the unfettered discretionary powers that pervaded the administrative agencies pertaining to three major public contracting realms: the concession contracts of public services, the public works procurement contracts, and the public supplies contracts. Thus, whilst a substantial number of provisions $^{13}$ were deployed to enunciate the general governing principles of administrative contracting, the remaining provisions of Title XIX on administrative contracts were dedicated to lay down detailed rules on the aforementioned three classical types of administrative contracts; namely, the concession of public services contracts, ${ }^{14}$ the public works procurement contracts, ${ }^{15}$ and the public supplies contracts. ${ }^{16}$

\section{Identifying the challenges encountered pre and post codification}

From the outset and throughout its four-decade lifespan, the rules on administrative contracts were replete with several serious setbacks which by and large rendered it particularly non-conspicuous in the ordinary life of the Ethiopian citizens.

First, in the process of codification of the Civil Code, Rene David stated thus: "I prepared the preliminary draft of the Code, but this draft, after it was translated into Amharic, ${ }^{17}$ was studied and revised, first by a Codification Commission made up of Ethiopians and then by the Ethiopian Parliament, which had the final power to adopt the text of the Civil Code". ${ }^{18} \mathrm{He}$ also stated that the task of the Commission was facilitated by expose des motifs ${ }^{19}$ that he submitted with the text of the preliminary draft. ${ }^{20}$ Contrary to this modus operandi, however, in the process of adopting the

\footnotetext{
${ }^{13}$ Arts 3131-3206 of Title XIX (Administrative Contracts) of the Civil Code of Ethiopia, 1960.

14 Arts 3207-3243.

15 Arts 3244-3296.

16 Arts 3297-3306.

17 Amharic is the working language of the Federal Government of Ethiopia; it is also the language widely spoken in Ethiopia.

18 David 1967: 146.

19 That is to say, statements of the background of and reasons for the provisions recommended.

20 David: 146.
} 
French principles on administrative contracts into the Civil Code of Ethiopia, Professor Rene David admits that there was probably a serious irregularity: that none of the said procedures was pursued for the title dealing with administrative contracts nor was it accompanied by expose des motifs. ${ }^{21}$ Thus, the then Codification Commission was not aided by expose des motifs which should have ordinarily accompanied the text of the preliminary draft as there were none prepared by the draftsman. This was exacerbated by other eventualities which the draftsman noted thus:

"It was translated into Amharic, but the Commission was otherwise occupied and apparently did not have time to go over the text in detail. At least, no comments or questions were sent to me concerning this title and it was not discussed with me. The preliminary draft became the proposal of the Commission without change, and it was adopted by Parliament without amendment."

This, the draftsman said, was "clearly regrettable" because "[i]n the case of the other titles, the discussion with the Commission resulted in improvements on the preliminary draft". ${ }^{22}$ He further noted:

"quite apart from the critical observations by the Commission, imperfections in my work became apparent to me as I was called upon to present it and discuss it with others. Title XIX was not the subject of such a discussion, and circumstances also prevented me from revising my preliminary draft six months or a year after finishing it. Thus, a mere preliminary draft, rather than a true proposal, became law, and it is beyond doubt that various imperfections resulted from this procedural failing". ${ }^{23}$

Secondly, the paucity of treatises on the French administrative contracts law written in the English language (at that time and counting!) rendered the understanding and immediate implementation of the rules illusive despite the draftsman's suggestion that one has to refer to the French treatises for the interpretations thereof. ${ }^{24}$ The rules on administrative contracts law were developed by the case-law of the French Council of State (Conseil d'Etat) and there was no "consolidation" by legislation of these principles by any country, including France; the basis for drafting the principles were only "scholarly writing" written in French language.

\footnotetext{
21 David 1967:146.

22146.

23 146-47. (Emphasis supplied.)

24147.
} 
Thirdly, there were no scholarly writings in Ethiopia which attempt to clarify the concepts and principles of the administrative contracts that had been enshrined into the Civil Code. The only veritable venture in that line was the one by George Grzeczunowicz. ${ }^{25}$ Professor Grzeczunowicz had to literally re-do the translation work into English to bring it to consonance to the French original preliminary draft which clearly showed that so much was lost in translation. ${ }^{26}$ That work evinced the inherent problems underlying the Ethiopian administrative contracts law.

Fourthly, unlike the French administrative law system, the Ethiopian administrative contracts law did not have administrative courts. ${ }^{27}$ In Ethiopia, with the advent of the administrative contracts law, there was no attempt to establish specialized administrative courts; it is, however, noted that both the High Court and the Supreme Court in Addis Ababa contained a division that dealt with government cases. ${ }^{28}$ It is not, however, chronicled anywhere as to when exactly these divisions became defunct.

Lastly, the administrative contracts law regime was dealt with a heavy blow by none other than a reputed arbitrator, Rene Dupuy, in one of the Libyan nationalization cases in the 1970s. What arbitrator Dupuy held, in the Texaco arbitration, ${ }^{29}$ was the antithesis of the arbitral ruling in Societe Rialet case. He held:

\begin{abstract}
"One should take into account here the fact that the theory of administrative contracts is somewhat typically French: it is consecrated by French law and by certain legal systems which have been inspired by French Law. But it is unknown in many other legal systems which are as important as the French system and it has not been accepted by international law, notwithstanding wishes which de lege ferenda may have been expressed in the field". ${ }^{30}$
\end{abstract}

Nevertheless, this argument was not convincing in the light of the fact that "[t]he concept of the droit administrative was adopted by many countries, whether they were

\footnotetext{
25 George Grzeczunowicz was a professor at the Faculty of Law, HaileSillasie I University (HSIU) [now Addis Ababa University] in the 1970s.

26 Part of the unofficial translation work is on file with the present author.

27 For more on this, see Bahta 2009:1-32.

28 David 1967: 144

29 (1977) 53 I.L.R, 389; (1978) 17 I.L.M.1.

30 Sornarajah 1986: 131. The administrative contracts law principles have indeed a wider acceptance in many of the civil law countries such as France, Belgium, Brazil, Argentina, Venezuela, Egypt, Libya, Saudi Arabia, Syria, Tunisia, Algeria, Spain, Portugal, and other former colonies of France.
} 
under the influence of the French legal system, such as Morocco, Tunisia, Lebanon and Algeria, or in those which were never French colonies. In particular, the ArabIslamic legal traditions facilitated the reception of the French public law characterization in all of the 22 member countries of the Arab league, as well as by the non-Arab Islamic countries in both Asia and Africa. When many Arabic Islamic countries gained independence after the Second World War, the Egyptian model, which was based on the French traditions, was introduced and formally adopted by many Arab states, such as Syria, Libya, Kuwait, Qatar, UAE, Saudi Arabia, as well as Iraq and Sudan". ${ }^{31}$ Furthermore, Belgium, Spain, Portugal and other civil law countries in Europe espouse the administrative contracts law regime. ${ }^{32}$ Mention can also be made of Brazil, Venezuela, Argentina, and Bolivia in South America. ${ }^{33}$

Eventually, what transpired following the incorporation of the administrative contract principles in the Ethiopian Civil Code of 1960 was critical paucity of reference materials in Ethiopia to which Ethiopian scholars can resort to for expounding on those principles. 34

\section{Peculiarities in Administrative Contracts Law}

Articles 3131-3306 of the Civil Code of Ethiopia are dedicated to what the Code calls "administrative contracts". ${ }^{35}$ These provisions deal with the regulation of contracts

\footnotetext{
31 Al-Saeed 2002: 150, 155.

32 For more, see Knutson, 2005.

33 Knutson, 2005.

${ }^{34}$ A course on "administrative contracts law" was being offered for the LL.B degree at the Addis Ababa University, Faculty of Law, which invariably was optional or elective.

35 Generally, "administrative contracts" may include: Public Service concessions contracts of which Public-Private Partnership (PPP) contracts (infrastructure outsourcing) may form a part; Economic Development Agreements (mineral and petroleum concessions contracts); Outsourcing public service providing (Public Service Delegation (PSD); e.g., transportation, urban solid waste management, gas, electricity and water supplies to a specific city, etc); Public Procurement Contracts (public works contracts, public supply contracts, services contracts, and consultancy services contracts); contracts for disposal of public assets; and, civil service employment contracts, etc. It should always be noted that in such contracts, one of the contracting parties is the "administrative authority", or "public body", which is an organ of the state functionary. Such bodies are defined under Arts 394-403 of the Civil Code. The applicability of the "Administrative Contract Principles", however, should be examined in the light of the following government entities: (i) the administrative bodies: Federal and State Governments, Federal ministries or State bureaus, commissions, authorities, agencies, services, offices, etc (ii) StateOwned-Enterprises (SOEs) or Public Enterprises, and (iii) business organizations where the Government has a majority or minority share-holding. The latter two seem to have been ousted from the ambit of the Public Procurement and Property Administration Proclamation No 649/2009.
} 
entered into by private parties, on the one hand, and administrative authorities, on the other. Such special contracts have historically developed under the French administrative law. This does not, however, mean that all contracts that are concluded by administrative authorities are classified as "administrative contracts"; rather contracts that are concluded by administrative authorities can be subject to either private law rules or administrative law rules. In other words, contracts entered into by administrative authorities (contrat de l'administration) are categorized into two classes: administrative contracts or private law contracts [ordinary civil contracts]. In order to realize the purpose of categorization, the Civil Code sets out certain criteria by which a contract, concluded with administrative authorities, is identified as an administrative contract. Art 3132 of the Civil Code stipulates thus:

"A contract shall be deemed to be an administrative contract where:

(a) It is expressly qualified as such by the law or by the parties; or

(b) It is connected with an activity of the public service and implies a permanent participation of the party contracting with the administrative authorities in the execution of such service; or

(c) It contains one or more provisions which could only have been inspired by urgent considerations of general interest extraneous to relations between private individuals."

Parties should, therefore, apply the afore-mentioned criteria in order to categorize whether a contract, entered into by administrative authorities, is one of administrative contract or not. It should also be noted that the administrative contract provisions in the Civil Code are not self-contained. Art 3131 provides thus:

“(1) Contracts concluded by the State or other administrative authorities shall be governed by the provisions of this Code which relate to contracts in general or special contracts.

(2) The provisions of this Title shall supplement or replace such provisions where the contract is in the nature of an administrative contract." (Emphasis supplied).

In other words, these provisions will have applicability under two circumstances: first, as gap-filling provisions whenever the general or special contracts laws fail to fully govern a contractual relationship. Secondly, they supplant those provisions that are inconsistent thereto. Thus, in a public supplies contract, for instance, the provisions enunciated under the "supply contracts" [articles 3297-3306] will firstly apply. 
Secondly, the contract of sale provisions may apply. ${ }^{36}$ Finally, where there is still a gap in the contractual relationship, the General Principles of Ethiopian Contract Law ${ }^{37}$ will be invoked for application.

What follows from the afore-said is the question, what contracts are "in the nature of an administrative contract"? In the French legal system, the issue is complex. Indeed, it has even demanded the establishment in 1872 of the French Court of Conflicts (Tribunal des Conflicts) whose function is the determination of jurisdictional disputes between the Conseil d'Etat and the Cour de Cassation. ${ }^{38}$ In its simplest form, however, Helen wrote:

“The subject matter jurisdiction of the Conseil d'Etat may be described as encompassing any cause of action arising out of activities of a service public, that is, any service performed to meet a public need by an officer or agent of public authority acting by virtue of that authority and exercising certain prerogatives unavailable in transactions between private parties."

In this regard, the Consei/39 is not bound by the French Civil Code of 1804; rather, it looks beyond the Code to unwritten principles on which to rest its fundamental concept of administrative justice in harmonizing the public need for efficient administration and individual enjoyment of private rights". 40

This bifurcation engendered the "development of separate theories of contract and tort law applicable only to the regulation of conduct between private parties on the one hand and governmental entities on the other". ${ }^{41}$ Thus, according to Helen, the Conseil

\footnotetext{
${ }^{36}$ Arts 2266-2426 of the ECC deal with contracts of sale, and contracts allied to sale.

${ }^{37}$ Arts 1675-2026 of the ECC deal with the general principles of contracts in Ethiopia.

${ }^{38}$ As Helen Cake noted "... the difficulty of enunciating a clear distinction between those matters traditionally reserved to the civil courts and those over which only an administrative tribunal may exercise control" still remains controversial. See Cake 1972: 321.

39 See Cake 1972: 321 wherein the author recounted the development of the French administrative courts in France as follows: The Conseil d'Etat was created by Napoleon in 1799; from its inception, the Conseil d'Etat has served as an arm of the executive, functioning initially as an informal body charged with planning and advising the head of the state and of resolving the difficulties which arise in the administrative field; the latter function was particularly vested in one of its five sections, i.e., the Commission du Contentieux which was renamed as Section du Contentieux in 1849. In 1872, the Conseil d'Etat was recognized as a fully independent tribunal. In 1953 and 1963, the Tribunaux Adminitratifs (local courts) were re-established to have original jurisdiction over the matters previously fell under the Conseil d'Etat giving the latter the status as the supreme administrative tribunal vis-à-vis the Court de Cassation, the supreme civil tribunal).
}

40323.

41323. 
tends to function "as a court of equity in adjudicating a fair balance between public and private interests and assuring that the latter be not restricted without ... due process of law". 42

Hence, the "administrative contracts" legal framework developed within the French administrative law with underpinning supposition that "contracts administratifs are negotiated between unequal parties and, therefore, '... Code provisions formulated to govern business practices between equals are not appropriate vehicles for the resolution of conflicts in which the public interest is of paramount importance'”. 43

Professors Mauro Cappelletti and Bryant Garth, thus, noted of the administrative courts in general as follows: 44

"[Administrative courts are] proven to be truly independent and impartial bodies, endowed with prestige of judicial courts, and maintaining fundamental standards of procedural fairness. At the same time, they are sufficiently specialized in the subject matters with which they have to deal, and sufficiently close, both organically and culturally, to the executive administration whose acts they have to review."

Arrowsmith, Linarelli and Wallace state that:

"[i]n most market economies, whilst there may be special provisions to govern the procedure for formation of contracts between a public body and its suppliers, the law which governs a contract once the contractual relationship has come into existence is the same, or substantially the same, as the law applying to contracts between private citizens". ${ }^{45}$

It is also stated that:

"[I]n some Civil Law countries, notably France, which has provided the model for a number of other systems, many public procurement contracts - those classified as contrats administratifs - are governed by a separate body of law from private contracts, which gives the government some unique privileges such as [...] special powers to terminate the contract, which are not enjoyed by private parties to a similar contract". ${ }^{46}$

\footnotetext{
42 Cake 1972: 326.

43 323; for more on this, see Nicholas 1982; Rudden 1991; Pollard 1998; Bell, Boyron \& Whittaker 1998.

44 Cappelletti \& Garth 1987: 58.

45 Arrowsmith, Linarelli \& Wallace 2000: 13-14.

46 13-14.
} 
Ethiopia is one of these countries which have adopted the French administrative contract law.

Three classical administrative contracts, i.e., concession of public services, public works contracts, and public supplies contracts have been ordinarily incorporated within the Civil Code as administrative contracts. To acquire the "administrative contracts" status, therefore, all other contracts by the administration should be qualified by the parties as "administrative contracts" under the second limb of Art 3132(a) or that the contract reserves exceptional powers to the administrative authorities (i.e., it contains clauses exorbitantes du droit commun) as enunciated under art 3132(c). In order for administrative authorities to bring other contracts into the realm of administrative contract law, it could have been possible to resort to a wider definition of what administrative contracts may potentially contain. For instance, administrative contracts are generally said to have the following three elements: 47

"(1) One of the contractors must be an administrator (government) or any public law entity;

(2) The contract must be geared towards regulating and facilitating public utility; ${ }^{48}$ or

(3) The contractors must choose public law provisions which are different provisions than those found in private law." 49

However, in Ethiopia, there has been no practice of resorting to such a recourse. Rather the parties have been inserting qualifying clauses only for those contracts already classified ipso jure as administrative contracts. Thus, in Ethiopia, administrative contracts have been limited to the aforesaid three classical types of administrative contracts. Accordingly, these administrative contracts can further be classified into two main categories: the public procurement contracts (which contain

\footnotetext{
47 Al-Saeed 2002:150, 156.

48 156, wherein the writer states that the concession of a public service constitutes an administrative contract par excellence since it deems to regulate and facilitate public utility.

49 156, wherein the writer explains by way of example that "the contract's provisions reserve for the administration certain special powers to modify the nature of the work or the manner of performance of the public service or even to terminate, unilaterally, the contract in a case of breach without recourse to any judicial process".
} 
public works contracts, and public supplies contracts) $)^{50}$ and the public services concession contracts.

Originally, thus, these administrative contracts law incorporated several principles that have no parallel principles in private law contracts which, inter alia, include: Tendering/ bidding law; 51 the doctrine of cause ${ }^{52}$ (causa: absence of cause and illicit cause); the non-applicability of exceptio non adimpleti contractus; the doctrine of supervision (the termination for convenience $(\mathrm{T} / \mathrm{C}))$; unforeseen supervening circumstances (imprevision); the doctrine of the act of government (fait $d u$ prince); the nonapplicability of specific performance remedy; and non-arbitrability. ${ }^{53}$ Below a brief explanation of each of these peculiar principles is worth our while.

\section{Exceptio non adimpleti contractus [Art 3177]}

The principle in private law contracting of a commutative or of synallagmatic nature is: "When in the case of a bilateral contract, correlative obligations are due for performance, either of the parties may abstain from the performance of his obligations, if the other party does not perform his obligations" ${ }^{54}$ In public law contracting, however, in order to ensure the continuity of providing public service or utility, a contractor cannot stop the performance on condition of being fully compensated for any loss suffered. ${ }^{55}$ Thus, this doctrine does not apply in public law contracting; the contractor is duty-bound to continue to perform its remaining obligations, notwithstanding that the procuring entity is way behind in discharging its obligations. It has to continue performing and, thereby, enabling the public service to remain undisturbed and unabated.

\footnotetext{
50 It is noteworthy that the procurement of services contracts, including consultancy services were not made part of it.

${ }^{51}$ Arts 3134-3169 of the Civil Code of Ethiopia.

${ }^{52}$ Articles 3170-71; for private law contracts, only "illicit cause" would be taken into account as per Art 1718 of the Civil Code.

${ }^{53}$ Art 315(2) of the Civil Procedure Code of Ethiopia of 1965 (where it is provided that disputes arising out of administrative contracts cannot be submitted to arbitration (i.e., private adjudication) for settlement).

54 Schneider \& Scherer 2005: 337.

55337.
} 


\section{State Contractual Adjustive Intervention/ Revision [Arts 3179-3193]:}

In this section, the procuring entity or the Government has three prerogatives which it can exercise in its contractual relations with private contractors. These are:

“(i) The Right of Supervision,

(ii) The doctrine of l'imprevision (Unforeseen Supervening Eventualities), and

(iii) The doctrine of fait du prince (Act of Government)."

Under the Right of Supervision, ${ }^{56}$ the procuring entity has both the varying right and the termination right. Furthermore, there should be two conditions for state intervention to adjust contractual term; viz., that there is no contractual clause inserted prohibiting the procuring entity to do so, and there is a change of circumstances which dictate a contractual adjustment in the general interest.

There should also be two conditions ${ }^{57}$ for resorting to the termination right; viz., that the contract has become useless to the public service, and/ or it has become unsuitable for its requirements.

In the implementation of such prerogatives, the contractor is entitled to compensation. The law provides for an important guiding-post in determining the quantum of compensation to the contractor; it also offers a choice to the contractor for opting-out (that is to say, to the termination right) whenever the adjustive intervention is a blow too heavy to withstand. ${ }^{58}$

The second prerogative is the doctrine of l'imprevision. ${ }^{59}$ This theory is based on the rebus sic stantibus principle, which is the venerable principle limiting the "sanctity of contract" theory (pacta sunt servanda). In discussing the doctrine, therefore, the two

\footnotetext{
${ }^{56} \mathrm{It}$ can be safely said that this intervention is predicated on the general understanding that government projects should be environmentally responsive, socially sensitive, economically viable, and politically feasible.

57 In the public works contracts, termination for convenience clause (convenience termination) upon quantum meruit compensation is stipulated under Art 59.4 cum 60.2 of the General Conditions of Contracts (GCC) of the Federal Standard Bidding Document for the Procurement of Works (SBDW), FPPA (2006). Note also similar entitlement, with some exceptions, for the employer's right to termination for convenience, under Clause 15.5 of the MDB Harmonized Edition of 2006. Reason: It is in the "Government's interest" to do so. Limitation: It must act in good faith.

58 Art 3182 of the Civil Code.

${ }^{59}$ For more on this, see Bahta 2016: 35-50.
} 
equally venerable contractual principles should be considered: The principle of Pacta sunt servanda (the sanctity of contracts) and the exceptions thereto clausula rebus sic stantibus $^{60}$ and the doctrine of force majeure.

The following are generally considered to be the constituent elements of Unforeseen Supervening Eventualities (“USE”):61

"(1) The event should be exceptional (i.e., infrequent, irregular, and rare),

(2) The event should be unforeseeable,

(3) The event should be general in character: the event affects a number of people or a certain category of people,

(4) The event should occur during performance, and,

(5) One of the parties must be exposed to excessive economic difficulties."

It is worth our while to note that, in Ethiopia, the doctrine does not purport to reestablish the contractual equilibrium between the parties; it only comes to play should the contractor suffer losses out of the contract due to the change in circumstances. In this respect, Art 3187(1) stipulates that the procuring entity should "leave a part of the loss at the charge of the contractor". It merely assists the contractor to entitle him to bring the procuring entity into the stormy boat to share in the exorbitant losses.

The size of the loss that the procuring entity will cover is to be, at first instance, negotiated between the parties. If the parties fail to strike a deal, the court will have to determine that amount. ${ }^{62}$ Thus, the ultimate destiny of the contract will be "termination" as the contractor cannot continue to perform indefinitely at a business loss, particularly in long-term contracts.

Finally, the extent to which the procuring entity shoulders the brunt of the losses depends on: (i) the efforts exerted by the contractor to mitigate the losses, (ii) the general position of the enterprise, and (iii) all equitable elements.

\footnotetext{
60 The principle encapsulates the idea that a contract remains valid only on the continuance of the circumstances obtaining at the time of its formation.

61 Arts 3183-85 of the Civil Code.

62 Art 3189 (3) of the Civil Code.
} 
Apart from equity and good faith in long-term contracts, the need to preserve an economic balance among the reciprocal performance requirements is the justification for espousing the doctrine. In the French administrative law contracting, it evolved from the principle of equality before public burdens (This principle was applied in the decision by Conseil d'Etat on March 30, 1916 which adjusted the contract entered into on March 08, 1904 for the lighting of the city of Bordeaux wherein the price of coal per unit surged from 28 francs at the time of contracting to 114 francs thereafter due to the sudden occupation by Germany of the territories from which coal was extracted). ${ }^{63}$

The third prerogative is the doctrine of fait du prince (the Act of Government) ${ }^{64}$. This intervention may be a measure of general applicability or particular applicability. Such measures of general applicability by state agencies can (i) directly modify the contractual terms, (ii) prevent the enforcement (application) of some of the contractual terms, or (iii) prematurely put an end to the contractual performance.

In such a situation, the contractor is entitled to compensation unless the "the measure of general application" specifically provided that there will be no compensation. Such state interventions, however, can impact the contractual relationship by either making the performance impossible or rendering the performance excessively onerous or more difficult. The former outcome is dealt with under the General Principles of Contract. The latter situation is, however, addressed under the doctrine of the Act of Government. According to this principle, the "measure of general application" may impact the contract by either (i) tampering with the content (provisions) of the contract, or (ii) simply disturb the situational circumstances for performing the contract obtaining at the time of making the contract. The latter case does not give rise to compensation unless the contract itself or the administrative measure itself provides for compensation.

If the intervention is of particular applicability, the effect is different. The Particular measure may be taken by the procuring entity itself or by a Non-contracting

\footnotetext{
63 Litvinoff 1985-86: 1-63.

${ }^{64}$ This is because the government has an inherent sovereign power to issue proclamations, regulations, directives (internal or of erga omnes effect), and circular letters. The Article mentions "laws, regulations, orders and other measures of general application made by the public authorities ... This is, thus, a manifestation of the theory of legislative supremacy."
} 
government Agency. The former case permits for compensation if the measure taken renders the contractual performance excessively onerous by either tampering with the contractual terms or disturbing the status quo. However, if the measure is eventuated by external economic factors, compensation is not granted to the contractor. When the measure is taken by a Non-contracting Agency, there will be no compensation. The contractor may, however, invoke the applicability of the "unforeseen supervening contingencies" to the impact of such measures as provided under Art 3193(2). The contractor may also resort to hold liable, ${ }^{65}$ under the administrative laws, the administrative authority which has implemented or proposes to take the measure.

Finally, specific performance ${ }^{66}$ cannot be ordered against a procuring entity. ${ }^{67}$ In lieu of that, damages may be awarded to compensate the contractor who has suffered from the non-performance of the contract. In other cases, whether the procuring entity can demand for the specific performance of the contractual obligations against the contractor is likely to be governed under the General Principles of Contract. ${ }^{68}$

\section{Is Administrative Contract Law still in force in Ethiopia?}

In this part, attempt is made to show how the administrative contracts law provisions in Civil Code have been gradually replaced by the promulgations of new laws particularly intended to deal with public procurement laws. In this respect, I will separately treat public contracting on public works and supplies, on the one hand, and concession of public services on the other hand.

\footnotetext{
${ }^{65}$ For tortuous liability, for example, one may need to consult Arts 2126-27, and 2137-40 of the Civil Code.

66 Specific performance is a contractual remedy by a creditor against the debtor to demand the performance in kind (in natura). The two closest definitions given are: "... a decree issued by the court which constrains a contracting party to do that which he has promised to do", and "... a process whereby the creditor obtains as nearly as possible the actual subject matter of his bargain, as opposed to compensation in money for failing to obtain it." See Zahraa \& Ghith 2000: 304-322.

67 For the interpretation of the provision by an Ethiopian court, see Imperial Highway Authority (IHA) $v$ Solel Boneh Ltd, Supreme Imperial Court of Ethiopia, May 14, 1965 reported in African Law Reports, vol. I., 1966 (wherein the Court ruled that, despite Art 3194, specific performance can be ordered to arbitration proceedings). For the ramifications of the court's interpretation of the Provision, see Bahta 2009: 18-19.

${ }^{68}$ Arts $1776-1778$ of the Civil Code.
} 


\section{Public Works and Supplies Contracts}

The first and second recitals of the Preamble to the Federal Financial Administration Proclamation No $57 / 1996^{69}$ purport to explain the policy rationale for its enactment. Accordingly, the Proclamation advanced the point that it was "essential to a wellfunctioning government" to have in place a "modern and efficient financial administration" and that the setting out of the basic concepts, principles and elements which govern the management of [the Federal Government's] financial resources was necessary. In both of the recitals, there was no indication of whatsoever nature as to the need or the justification for the enactment of rules pertaining to the public procurement system for the Federal Government which hitherto was by and large governed under Administrative Contracts Law provisions. ${ }^{70}$ The Proclamation's purpose seemed to have been centered on the establishment of a modern and efficient financial management system. It, however, went out of its way and provided, under Art 48, for a stipulation that federal property should only be "acquired and disposed of" in accordance with relevant Council of Ministers' regulations to be issued thenceforth. ${ }^{71}$ The Country Procurement Assessment Report (CPAR) did not make any reference to the administrative contracts law in the Civil Code. ${ }^{72}$ Conventionally,

69 Federal Government of Ethiopia Financial Administration Proclamation No 57/1996, Fed. Neg. Gazeta, Year 3, No 14, 19 December 1996

70 It should be noted, though, that substantial number of contracts by administrative authorities were qualified as "administrative contracts", with little or no resort to the principles embedded therein; the "qualifying clauses" were invoked only when submission of disputes to arbitration were at stake.

71 See also DAG Ethiopia: Harmonization Action Plan (2004-2006), available at http://dagethiopia.org/new/images/EthiopiaHarmonisationActionPlanDec04.pdf/ [accessed 01-012017] (wherein it is stated, at page 7, that "the enactment of the Financial Law (Dec 2006) had provisions for public procurement, marking the beginning and leading to subsequent reforms in procurement"). It also stated, at page 8, that "The Ethiopian government procurement directive conforms to the UNCITRAL Model on Procurement of Goods, Construction and Services. Ethiopia's procurement directive is comparable to the procedures used by the Multilateral Development Banks and many bilateral donors. A new procurement directive is being drafted which will accommodate the requirements of regional governments and donors". This document doesn't at all make any reference to the administrative contracts in the Civil Code as forming part of the public procurement system in Ethiopia.

72 See Ethiopia: Country Procurement Assessment Report (CPAR): Findings and Recommendations, Vol. I (June 28, 2002, revised March 27, 2003). The CPAR instead found, at page 3, that procurement was regulated by (a) the Financial Proclamation No 57/1996 which constituted the procurement law and dealt with procurements and contracts by public bodies; (b) the Financial Regulation No 17/1997 issued by the Council of Ministers, and (c) the Ministry of Finance Directives - procurement and contracts, June 1997. It further pointed out that Arts 68 and 69 of the Financial Proclamation authorize the issuances of "regulations" and "directives" by the Council of Ministers and Ministry of Finance respectively. Further, it is noted that the Financial Regulation dealt with procurement principles, suppliers list, bid and performance securities and progress payment. It, thus, concluded by stating that, as the MOF directives, revised in 1999, were only suitable for the procurement of goods (except 
the modalities of acquisition of public property would include transfers, donations, leases and purchases. The mandate granted to the Council of Ministers (CoM) to issue pertinent regulations was accentuated by virtue of Art 56 of the said Proclamation, which stated thus, "all goods and services shall be procured on the basis of directives issued by the Ministry, and these directives shall outline the manner in which goods and services are procured ...". It is a trite fact that the public procurement law system is designed towards the effective acquisition of public property through leases and purchases of supplies, services, and construction works. Thus, that Proclamation opened a new door for the Council of Ministers to undertake a foray into the governance of the sophisticated system of the public procurement in Ethiopia. Further, the said Proclamation directly addressed the issue of public procurement contracts by bringing into its fold the issues of "public procurement and government contracting" under Arts 54 through 57. The need for reforming the administrative contracts law regime was particularly evident as the Proclamation had to address the public procurement system head-on. Art 56 of the Proclamation stated thus:

"[a]ll goods and services shall be procured on the basis of directives issued by the Ministry, and these directives shall outline the manner in which goods and services are procured and the form in which information pertaining to such procurement is made public".

The combined reading of Articles 48 and 56 of the Proclamation, thus, show that the mandate of revising the rules governing government contracting rested on the Council of Ministers (CoM) and the Minister of MoFED. Eventually, the CoM issued Regulation No 17/97, which, inter alia, encapsulated procurement contracts consisting of several provisions (i.e., arts $66-73) .{ }^{73}$ Article 73 thereof stated thus:

"Without limiting the special provisions of these regulations, government procurement shall be governed by the provisions of administrative contracts under the Civil Code of Ethiopia".

This legal stipulation, thus, rendered the administrative contracts rules in the Civil Code amenable to Regulation No 17/97. In other words, the afore-mentioned Regulation lowered the status of those rules from a parliamentary legislation, as they

vehicles) and, thus, did not include the procurement of works and cover only partially consulting services, and therefore, not comprehensive.

${ }^{73}$ Council of Ministers Financial Regulations No 17/1997, Fed. Neg.Gaz., Year 3, No 46, 1 July 1997. 
were, to a subsidiary regulation by bringing them into its fold. Furthermore, those administrative contracts provisions in the Civil Code had to apparently cling on to Art 73 of the Regulation for their continued relevance and applicability in the public procurement plane.

Finally, the promulgation of the Public Procurement Proclamation No 430/2005 expressly and sweepingly repealed Arts 54-56 of Proclamation No 57/96 and Arts 6673 of Regulation No 17/97. Thus, Art 73 of the Regulation No 17/97, which sustained the administrative contracts law had been deprived of life itself, so to say, and with it the edifice of administrative contracts law (to be more pertinent, the public works contracts and the supplies contracts law provisions) collapsed!

Thereafter, contract documents for the procurement of goods, services, and public works which previously used to be drawn up individually by procuring entities and which invariably qualified their contracts as "administrative contracts" gave way to the Standard Conditions of Contract (referred to as PPA (2006)) drawn up by the Federal Public Procurement Agency, which was established by virtue of the Federal Public Procurement Proclamation No 430/2005. ${ }^{75}$ These general and special conditions of contract did not make any reference to administrative contract rules whatsoever. In 2009, the Federal Procurement and Property Administration Proclamation No $649 / 2009^{76}$ was enacted. By virtue of this new Proclamation, the old Proclamation No $430 / 2005$ was repealed, with no hope of resuscitating the administrative contracts law regime. Instead, Art 46(4) of the newly enacted Proclamation, captioned "Notification of Award and Signing of Contract", enjoined the Minister to issue directives which prescribe the procedures that public bodies have to follow in administering contracts. Subsequently, the Minister issued the implementing directive which has, inter alia, consisted of a number of provisions on "contract administration" ${ }^{77}$ It particularly deals

\footnotetext{
${ }^{74}$ Public Procurement Proclamation No 430/2005, Fed. Neg. Gaz., Year 11, No 15, 12 January 2005, Art 56.

${ }^{75}$ See Arts 8-16. Art 11(4), thus, granted the Agency the power to "prepare, update and issue authorized versions of the standard bidding documents, procedural forms and any other attendant documents to procuring entities" deviation from which can be effected only with prior written approval of the Agency. For more on this, see Bahta 2013: 46-78.

${ }^{76}$ Federal Public Procurement and Property Administration Proclamation No 649/2009, Fed. Neg. Gaz., Year 15, No 60, September 2009 (“Proclamation No 649/2009”).

77 MoFED, Federal Public Procurement Directive, June 2010, see particularly Part 7 (Arts 28-29) and Art 49 on force majeure. For the text of the Directive (both in English and Amharic languages), see
} 
with force majeure, performance of procurement contracts (Art 28), contract performance follow-up (Art 29), and completion of contracts (Art 30). Consequently, in 2011, the Federal Public Procurement and Property Administration Agency (FPPPAA) issued standard general conditions of contract (GCC) for the procurement of works, services, and goods based on which all federal procurements of works, services, and goods should be obtained. Unlike those one-off previous contractual terms which were individually drawn up by the procuring entities, all these new general conditions of contract, as can be seen in the Directive, do not contain any reference whatsoever to the administrative contracts law regime in the Civil Code. There is no doubt, thus, that the FPPPAA, by not making any reference, express or implied, to the possibility for application of the administrative contract provisions in the 2006 and 2011 suite of GCCs, has clearly shown that those provisions have been stripped of any legal force.

It can be safely concluded, therefore, that the provisions on the public works contracts (arts 3244-3296) and those on public supplies contracts (arts 3297-3306) have been effectively substituted by the public procurement proclamation, the directive and the GCCs currently in force.

\section{Public Service Concessions}

The provisions relating to the concessions of public services, however, warrant a separate treatment here.

Article 3207 defines the meaning of both "public services" and "concession contracts". Thus, "public service" constitutes:

"any activity which a public community has decided to perform for the reason that it has deemed it to be necessary in the general interest and considered that private initiative was inadequate for carrying it out".

Public Services Concession contract ${ }^{78}$ is also defined as:

http://www.ppa.gov.et/index.php?option=com_joomdoc\&view=documents\&path=legislation\%2Fdirecti ves\%2Fprocurement\%2Fpublic-procurement-directive-englishpdf [Accessed 01-01-2017].

78 The expansion of the concession practices can be traced back to the transient Italian occupation period of Ethiopia (1928-1933 E.C). Unwelcome developments as these were, however, they were rendered null and void soon after the restoration of the Crown to its Throne at the end of WWII. The Concession (Revocation) Proclamation No 49/1936 (E.C) revokes all concessionary grants on mining operations, agricultural development, electricity, water, transport, hotel, and other public service 
"... the contract whereby a person, the grantee, binds himself in favour of an administrative authority [grantor] ${ }^{79}$ to run a public service getting a [sic] remuneration therefor by means of fees received on the use thereof".

Currently, the Public Services Concession contract seems to manifest itself in three forms. Firstly, there is public services delegations (PSD) by administrative authorities to private investors or Public Services Providing (PSP) by private investors in addition to or in lieu of the administrative authorities. This arrangement falls squarely within the ambit of the definition. Nevertheless, it should be distinguished from the "procurement of Services Contracts" as the former calls for a concessionary agreement wherein a private contractor provides the designated public services to the end-users and amortize its project financing from the user-generated revenues. The "procurement of Services Contracts", however, is a method whereby a contractor provides the designated services to the procuring entity itself in cases, where the procuring entity opts for the contracting-out of the services rather than the traditional in-house providing. The procurement of service contracts may, therefore, involve insurance, air transportation, cleaning and janitorial, security, equipment maintenance, consultancy and training services, architectural and engineering services, etcetera.

Secondly, Public-Private Partnership (PPP) contracts $^{80}$ (infrastructure outsourcing): this includes concessions for the design, construction, financing, operation, maintenance and/ or management of a certain public infrastructure projects (facilities) such as toll-roads, tramways, railways, light-rail-transits (LRT), tolled-tunnel projects, waste-management facilities, suspension bridges, etc.

In the Ethiopian procurement law, the modalities for effectuating PPP contracts had been included under the procurement of public works contracts as defined under Art

providing concessionary grants conceded during the Italian occupation. See Art 2 of Proclamation No 49/1936 E.C.

79 It can also be referred to as the "concedant authority" or the "conceding authority".

80 Art 2(27) of Proclamation No 649/2009 stipulated thus: "Public-Private Partnership" means "investment through private sector participation by a contractual arrangement between a public body and a private sector enterprise, as the concessionaire, in which the concessionaire: (a) undertakes to perform or undertake any construction project or service or lease concession; (b) assumes substantial financial, technical and operational risks in connection with the performance of a public function or use of government property; and, (c) receives consideration for performing a public function or utilizing government property, by way of fees from any public funds, user levies collected by the concessionaire from users or customers for a service provided by it, or a combination of such consideration". 
2(3) of Proclamation No 649/2009.81 The definitional provision states that the procurement of public works includes "Build-Own-Operate" (BOO), "Build-OwnOperate-Transfer" (BOOT), and "Build-Operate-Transfer" (BOT) contracts. These are modalities of contractual engagement for Public-Private Partnerships. However, it should be noted that the system of PPP contracts is already maturing to the extent that it now enjoys the status of discreet conceptualization and separate legal framework. Thus, Art 2(27) of the Proclamation set forth the legal attributes and definitional skeleton of PPP contracts. In addition to the definitional framework, Art 34 of the same also stipulates that the Minister of Finance and Economic Development (MoFED) would issue Directives ${ }^{82}$ that prescribe rules "governing its formation" and the modes of implementation thereof. Thus, whilst PPP contracts have been extensively put in place particularly in the power generation sector, short of legislative framework, through contractual arrangement, a full-fledged draft of the Public-Private Partnership Law has been recently made public. ${ }^{83}$

Finally, with regards to the Mining and Petroleum concession contracts ${ }^{84}$, worthy of mention is the legislator's intention to divorce mining concessions from the administrative contracts legal regime. It is provided thus: 85

"Unless otherwise provided by agreement, the provisions of the Civil Code of Ethiopia regarding administrative contracts shall not be applicable to such agreements that may be concluded between the Government and the licensee."

It is clear that the only way administrative contracts law find application is by incorporating their application in individual mining concession agreements. As can be shown in the subsequent Model Mining Agreement or specific agreements, ${ }^{86}$ however, this has been far from reality. It should, thus, be noted that "mining concession

\footnotetext{
81 Federal Public Procurement Proclamation No 649/2009, Fed. Neg. Gazeta, Year 15, No 60, 9 September 2009.

82 This Directive is expected to heavily draw on the UNCITRAL Legislative Guide on Privately-Financed Infrastructure Projects (2001). See UNCITRAL, 2001.

${ }^{83}$ The text of the Draft Proclamation is on file with the author.

${ }^{84}$ Due to their strategic importance and the involvement of MNCs, these contracts are highly politicized. Thus, they are better dealt with under international laws on Foreign Investment Protection.

85 Mining Proclamation No 52/1993, Negarit Gazeta, Year 52, No 42, 23 June 1993, Art 55(2).

${ }^{86}$ See Mining agreement between Ethiopia and Nyota Minerals (Ethiopia) Ltd relating to the Tulu Kapi Mining Operations, 21 March 2012 (On file with the author).
} 
contracts" in Ethiopia are expressly placed outside of the ambit of the administrative contracts rules by virtue of Art 55(2) of the Mining Proclamation No 52/1993. ${ }^{87}$

In mining and petroleum concession contracts, foreign investors negotiate for an inclusion of a "stabilization clause" to "protect the contract from application of legislative or administrative measures subsequent to the conclusion of the contract". ${ }^{88}$ The existing petroleum law stipulates for the possibility of incorporating a "stabilization clause" 89 in petroleum concession contracts in Ethiopia by virtue of which such contracts insulate the applicability of those prerogatives that could have been exercised under the administrative contracts laws.

\section{Whether disputes involving administrative contracts can be submitted to arbitration}

Parties to civil and commercial disputes are generally entitled to submit their disputes for private adjudication or arbitration. However, it is said that as much as "in principle, any dispute should be just as capable of being resolved by a private arbitral tribunal as by the judge of a national court", ${ }^{90}$ it is also true that "[e]ach state decides which matters may or may not be resolved by arbitration in accordance with its own political, social and economic policy". ${ }^{91}$ Accordingly, Article 315(2) of the Civil Procedure Code of Ethiopia classifies disputes arising out of administrative contracts as those matters

\footnotetext{
87 Mining Proclamation No 52/1993, Negarit Gazeta, Year 52, No 42, 23 June 1993. The Mining Proclamation No 52/1993 also stipulated that "any dispute, controversy or claim between the Government and the licensee" would be settled through arbitration failing negotiation. This clause enabled the submission of disputes arising out of mining agreements which otherwise would not have been possible as discussed below.

${ }^{88}$ See Peter 1998: 876 (wherein the author points out that there are three legal techniques to do so: These are (i) Provisions simply prohibiting subsequent enactments affecting the investor's rights, (ii) the anti-inconsistency rule (the agreement will prevail over future legislation or regulation if there is inconsistency between the two; (iii) the host country's municipal law may be incorporated in the contract and "frozen" at a specific date. Such a clause, thus, serves foreign corporations to stabilize laws relating to (i) property, (ii) the fiscal regime, (iii) labor legislations, (iv) export and import provisions, (v) currency legislations for purposes of free transferability of profits or compensations, and (vi) the general legislative and contractual framework.

89 Petroleum Operations Proclamation No 295/1986, Negarit Gazeta, Year 45, No 6, 26 March 2006.

90 Blackaby, N., Partasides, C., Redfern, A. \& Hunter, M. 2009: 123-124.

91 123-124. See also s 2 of the South African Arbitration Act (wherein it is provided that "(a) any matrimonial cause or any matter incidental to any such cause or any matter relating to status" is not permissible for reference to arbitration. Similarly, s 7 of the Botswana Arbitration Act prohibits the submission to arbitration of disputes in relation to criminal cases, matters relating to status, matrimonial causes, and matters in which minors or other persons under legal disability may be interested.
} 
which are incapable of being submitted to arbitration for settlement. Article 315(2) of the Civil Procedure Code of Ethiopia provides thus:

"No arbitration may take place in relation to administrative contracts as defined in Art 3132 of the Civil Code or in any other case where it is prohibited by law."

As has been discussed earlier on, in Ethiopia, only few legal scholars are conversant with the contents or the legal provisions of the administrative contracts law. The said provisions have been of less concern to law students and practitioners in Ethiopia. Rather it has been of more interest due to what has been a controversial issue at the center of administrative contracts: whether disputes arising out of or in connection with administrative contracts can be submitted to arbitration for settlement.

The afore-mentioned legal provision prohibits in no uncertain terms the submission of disputes arising out of administrative contracts. However, some have argued the provision has fallen into desuetude. ${ }^{92}$ This is due to the consistent practice, notwithstanding the "prohibitive" clause, of arbitrating administrative contract disputes and the non-applicability of administrative contracts in reality. Courts have, also, been divided in their position in this respect. ${ }^{93}$ This contention has, however, become academic due to several reasons. Firstly, many public bodies which are likely to engage particularly in international procurement transactions have incorporated clauses in their respective establishment regulations enabling them to submit disputes to arbitration. ${ }^{94}$ Secondly, the multilateral development banks have shown commitment to use the Multilateral Development Banks (MDB) Harmonized Edition (2006) for infrastructure projects funded wholly or partly by them. Third, bilateral donors and regional development banks also use FIDIC (Red Book) of 1999 and their peculiar standard bidding documents such as the European Development Fund (EDF)

\footnotetext{
92 Shimelash 1994: 69-94.

${ }^{93}$ In the case of EthioMarketing Ltd $v$ Ministry of Information, the Ethiopian Supreme Court (Civil Case No 1144/67 [1975], unreported) decided that: "A contract concluded pursuant to the provisions of the Civil Code is law between the two parties. The appellant and the respondent having, on the basis of the Civil Code, agreed to resolve the dispute between them by arbitration, the Civil Procedure Code should not prevent the enforcement of this contractual agreement". Arguably, this decision does not comfortably sit with Art 315(2) of the Civil Procedure Code which expressly prohibits the submission to arbitration of disputes arising out of administrative contracts. In what seems to have been a corrective move, the High Court, in the case of Water Supply and Sewerage Authority v Kundan Singh (Civil Case No 688/79 [1986], unreported) decided that Art 315(2) prevailed over any conflicting Civil Codal provisions.

${ }_{94}$ For more on this, see Bahta 2009: 1-32.
} 
standard bidding document. Fourth, the tacit approval by the Federal Supreme Court (Cassation Division) for arbitrability of administrative contracts in re ZemZem PIC $v$ Illubabor Zonal Department of Education ${ }^{95}$ have been militating in favor of the arbitrability of administrative contracts. Finally, the standard conditions of contract prescribed in 2011 by the Federal Public Procurement and Property Administration Agency (FPPPAA) to be used by all federal procuring entities on the procurement of public works, goods, and services (including consultancy services) do not contain any clause that impliedly or expressly call for the application of the administrative contracts. Contrary to this, the Ethiopian procurement system prescribes that, in international procurements, “... general and special conditions of contract shall be of a kind generally used in international trade" 96 and that "contracts concluded for procurements to be made by means of international competitive bidding may incorporate standard terms and conditions applicable in international commercial transactions to the extent that such terms and conditions are not in conflict with the Proclamation, this Directive and other documents governing public procurement". ${ }^{97}$ The inclusion of such terms and conditions as applied in international commercial transactions no doubt would call for the submission of disputes to neutral international arbitrations in neutral forums.

\section{Judicial Practice on the Application of the Provisions on Administrative Contracts}

Notwithstanding the evolving legal environment, which does not seem to recognize the relevance and viability of administrative contracts in the Ethiopian legal system, new developments have been witnessed as of late. As Oliver Wendell Holmes wrote, as early as 1872, "... it was 'not the will of the sovereign that makes lawyers' law... but what ... the judges, by whom it is enforced, say is his will'". ${ }^{98}$ Thus, notwithstanding the clear repeal of the provisions in the administrative contracts law, the courts are still willing to apply whenever its application is called for by the parties. The Federal

\footnotetext{
${ }^{95}$ ZemZem PLC v Illubabor Zonal Dep't of Education, Cass. Case No 16896 [2006], 2 Fed. Sup. Ct. Rep. 75.

${ }^{96}$ Art 59(3)(f) of Proclamation 649/2009.

${ }^{97}$ Art 17.4(g) of the Federal Public Procurement Directive, June 2010

98 Holmes 2009: xix.
} 
Supreme Court (Cassation Division) recently decided on two cases involving whether a contract was in the nature of an administrative contract, ${ }^{99}$ and on the interpretation and application of the provisions [arts 3196-3197] on interest for default of payment. ${ }^{100}$

In the light of this, if the law is what the courts say it is, then, administrative contracts are still in force. What is paradoxical is, however, the legislator has long expressly repealed the administrative contracts legal regime and those on-the-know and entrusted with the mandate to supervise and implement the Ethiopian public procurement system, such as the Ministry of Finance and Economic Cooperation (MoFEC) and the Federal Public Procurement and Property Administration Agency (FPPPAA) have been consistent in complying with the legislator's intention.

\section{Conclusion}

It is a trite fact that public procurement system involves the planning phase, the tendering phase and the contract administration phase. Prior to the modernization of the Ethiopian public procurement system in 2005 through the incorporation of the UNCITRAL Model Law on the Procurement of Goods, Construction and Services into the Public Procurement Proclamation No 430/2005, Ethiopia did not have a coherent and consolidated legal document on public procurement. In 1960, with the promulgation of the Civil Code, administrative contracts were introduced into the Ethiopian Civil Code which contained a body of the consolidated French case law on administrative contracts. These rules remained archaic and largely irrelevant for the last four decades prior to its repeal pursuant to Art 56 of the Public Procurement Proclamation No 430/2005. And yet this legislative act has not been well noticed by legal scholars and practitioners. Nor did the courts take cognizance of this situation.

Consequently, despite the continuing modernization processes of the public procurement system in Ethiopia in a bid to achieve transparency, accountability, efficiency, value-for-money, and towards nation-wide harmonization thereof whether

\footnotetext{
99 Weyra Wood and Metal Works Cooperatives Ltd v Bureau of Trade and Industrial Development of the Addis Ababa City Administration, Cass. Case No 80464 [2013], 14 Fed. Sup. Ct. Rep. 113.

100 Debebe Derese General Contractor v Office of Water, Mining, and Energy of the District of Fentale, Cass. Case No 95797 [2015], 17 Fed. Sup. Ct. Rep. 104.
} 
the administrative contracts principles, as enshrined under the Civil Code of 1960, are still relevant in the contract administration phase of public procurements leaves us in limbo.

In this regard, there is a need for a clear pronouncement of whether administrative contracts should form part and parcel of the public procurement system in Ethiopia or it is time to bid it farewell. After all, there is such an instance where the administrative contracts legal regime has been expressly maintained through legislation. ${ }^{101}$

101 Tigray Public Procurement Proclamation No 123/2006 (repealed), Negarit Gazeta Tigray, Year 15, No 8, 10 February 2006 (In Art 71 it is stated that subject to the procurement proclamation, public procurement contracts should be governed by the administrative contracts provisions in the Civil Code). 


\section{Bibliography}

Al-Saeed, M. 2002. Legal Protection of Economic Development Agreements. 17 Arab Law Quarterly 17:150-176.

Arrowsmith, S., Linarelli, J. \& Wallace, D Jr. (Eds.). Regulating Public Procurement: National and International Perspectives. Kluwer Law International.

Bahta, T H. 2013. The Regulatory Framework for Public Procurement in Ethiopia. In Quinot, G. \& Arrowsmith, S. (Eds.). Public Procurement Regulation in Africa. Cambridge: Cambridge University Press.

Bahta, T H. 2009. Adjudication and the arbitrability of Government Construction contracts in Ethiopia. Mizan Law Review 3:1-32.

Bahta, T H. 2016. Framework Procurement Contract in Ethiopia. Public Procurement Law Review 25:35-50.

Bell, J., Boyron, S. \& Whittaker, S. (Eds.). 1998. Principles of French Law. Oxford: Oxford University Press.

Blackaby, N., Partasides, C., Redfern, A. \& Hunter, M. 2009. Redfern and Hunter on International Arbitration. 5 ed. Oxford:Oxford University Press.

Cake, HM. 1972. The French Conseil d'Etat - An Essay on Administrative Jurisprudence. Administrative Law Review 24:315.

Cappelletti, M. \& Garth, B. 1987. Civil Procedure: Introduction- Policies, Trends and Ideas in Civil Procedure. In Cappelletti, M. (Ed.). International Encyclopedia of Comparative Law.

David, R. 1967. Administrative Contracts in the Ethiopian Civil Code. Journal of Ethiopian Law 4:145.

Development Assistance Group ETHIOPIA, 2004. Ethiopia: Harmonization Action Plan (2004-2006), [online]. Available at <http://dagethiopia.org/new/images/EthiopiaH armonisationActionPlanDec04.pdf/> [Accessed 01-01-2017]. 
Government of Ethiopia, 2010. Ministry of Finance \& Economic Development. Federal Public Procurement Directive.

Holmes, O W. 2009. The Common Law. Cambridge: Harvard University Press.

Knutson, R. (Ed.). 2005. FIDIC: An Analysis of International Construction Contracts. The Hague: Kluwer Law International.

Litvinoff, S. 1985-1986. Force majeure, Failure of Cause and Theorie de l'imprevision: Louisiana Law and Beyond. Louisiana Law Review 46:1-63.

Nicholas, B. 1982. The French Law of Contract. 2 ed. London: Butterworths.

Peter, W. 1998. Stabilization Clauses in State Contracts. International Business Law Journal 7:875.

Pollard, D. 1998. Sourcebook on French Law. 2 ed. London, Sydney: Cavendish Publishing Ltd.

Rudden, B. 1991. A Sourcebook on French Law. 3 ed. Oxford: Clarendon Press.

Schneider, M. \& Scherer, M. 2005. Switzerland. In Knutson, R. (Ed.). FIDIC: An Analysis on International Construction Contracts. The Hague: Kluwer Law International.

Shimelash, B. 1994. The Formation, Content and Effect of an Arbitral Submission under Ethiopian Law. Journal of Ethiopian Law 17:69-94.

Sornaraja, M. 1986. The Pursuit of Nationalized Property. Martinus Nijhoff Philosophy Library, Springer.

United Nations Commission on International Trade Law. 2001. Legislative Guide on Privately Financed Infrastructure Projects (54 ${ }^{\text {th }}$ session, Supplement No 17). New York: United Nations.

World Bank. 2002. Ethiopia - Country Procurement Assessment Report: Findings and recommendations, Revised March 27, 2003. Washington, DC: World Bank. 
Zahraa, M. \& Ghith, A A. 2000. Specific Performance under the Vienna Sales Convention, English Law and Libyan Law. Arab Law Quarterly 15:304-322.

Jurisprudence:

Debebe Derese General Contractor v Office of Water, Mining, and Energy of the District of Fentale, Cass. Case No 95797 [2015], 17 Fed. Sup. Ct. Rep. 104.

EthioMarketing Ltd $v$ Ministry of Information. Civil Case No 1144/67 [1975], unreported.

Imperial Highway Authority (IHA) v Solel Boneh Ltd, Supreme Imperial Court of Ethiopia, May 14, 1965. African Law Reports vol. I., 1966.

Water Supply and Sewerage Authority v Kundan Singh. Civil Case No 688/79 [1986], unreported.

Weyra Wood and Metal Works Cooperatives Ltd v Bureau of Trade and Industrial Development of the Addis Ababa City Administration, Cass. Case No 80464 [2013], 14 Fed. Sup. Ct. Rep. 113.

ZemZem PLC v Illubabor Zonal Dep't of Education, Cass. Case No 16896 [2006], 2 Fed. Sup. Ct. Rep. 75.

Legislation, Regulations \& Proclamations:

Arbitration Act 42 of 1965 (South Africa).

Arbitration Act (Cap 06:01) (Botswana).

Civil Code of Ethiopia, 1960.

Civil Procedure Code of the Empire of Ethiopia, 1965.

Council of Ministers Financial Regulations No 17/1997 in Federal Negarit Gazeta, $3^{\text {rd }}$ Year No 46 (01-07-1997) (Ethiopia). 
Determining Procedures of Public Procurement and Establishing Supervisory Agency Proclamation No 430/2005 in Federal Negarit Gazeta, Year 11 No 15 (12-01-2005) (Ethiopia).

Federal Public Procurement and Property Administration Proclamation No 649/2009 in Federal Negarit Gazeta, Year 15 No 60 (09-09-2009) (Ethiopia).

Mining Proclamation No 52/1993 in Federal Negarit Gazeta, Year 52 No 42 (23-061993) (Ethiopia).

Petroleum Operations Proclamation No 295/1986 in Federal Negarit Gazeta, Year 45 No 6 (26-03-2006) (Ethiopia).

Telecommunication Proclamation No 49/1996 in Federal Negarit Gazeta, $3^{\text {rd }}$ Year No 5 (28-11-1996) (Ethiopia).

Tigray Public Procurement Proclamation No 123/2006 in Negarit Gazeta Tigray, 3rd Year 15 No 8 (10-02-2006) (Ethiopia). 